\title{
PERLINDUNGAN TERHADAP PASAR TRADISIONAL DI TENGAH EKSPANSI PASAR RITEL MODERN
}

\author{
Afif Noor, IAIN Walisongo Semarang
}

\begin{abstract}
Modern retail market, especially in Central Java experiencing tremendous growth lately, based on the data, in 2004 the number reached 1,496 traditional markets, while the modern market amounted to 232. Different conditions occurred in 2008, the number of traditional market just reached 1,443 while the modern market reached 399. That means there is a negative growth in traditional markets. In 2010 the modern retail market growth reached 10.2\% (1,852 outlets). This condition is one side has a positive effect because it means showing the high investment in the real sector, but on the other result in the more traditional markets entrapment, especially the modern retail market using the franchise system to begin operations 24 hours per day. Therefore, the protection of traditional markets as the center of economic activities of small and medium-sized enterprises should be done to ensure the sustainability of small and medium enterprises.
\end{abstract}

Kata Kunci : Perlindungan, Pasar tradisional, Pasar modern

\section{Pendahuluan}

Pertumbuhan dan perkembangan pasar ritel modern akhir-akhir mengalami peningkatan yang luar biasa dibanding dengan pertumbuhan dan perkembangan pasar tradisional ${ }^{1}$. Secara nasional dalam lima tahun terakhir peningkatan omset ritel modern mengalami peningkatan cukup pesat, yang didukung oleh pertumbuhan jumlah ritel yang pesat yaitu mencapai 18.152 gerai pada 2011. Jumlah ini mengalami peningkatan yang signifikan jika dibandingkan pada tahun 2007 yang berjumlah 10.365 gerai. Menurut Asosiasi Perusahaan Ritel Indonesia (Aprindo) pertumbuhan bisnis ritel di Indonesia

\footnotetext{
${ }^{1}$ Ada empat macam jenis pasar ritel modern yaitu hypermaket, supermarket, minimarket dan pertokoan. Sedangkan kategori pasar tradisional adalah pasar kota, pasar wilayah dan pasar lingkungan
}

Volume IV/Edisi 2/November 2013 
antara $10-15 \%$ per tahun. Sedangkan nilai penjualan ritel kalau pada tahun 2006 masih sebesar Rp 49 triliun, namun melesat hingga mencapai Rp 100 triliun pada 2010. Pada tahun 2011 pasar ritel modern mengalami pertumbuhan 10\%-15\% atau nilai penjualan mencapai Rp 110 triliun. Kenaikan jumlah gerai ritel ini terutama dipicu oleh pertumbuhan gerai minimarket yang fenomenal. Jika pada 2007 total gerai minimarket hanya 8.889 maka pada 2010 melonjak pesat hingga mencapai sekitar 15.538 buah. Sedangkan pada 2011 diperkirakan akan meningkat menjadi 16.720 gerai. Pertumbuhan bisnis minimarket ini didominasi oleh pertumbuhan outlet Indomaret dan Alfamart, dengan frekuensi pertambahan jaringan relatif cepat dan penyebaran yang cukup luas, baik melalui pola pengelolaan sendiri (reguler) maupun melalui sistem waralaba (franchise) ${ }^{2}$.

Pertumbuhan pasar ritel modern secara nasional semakin meningkat tajam seiring dengan masuknya beberapa perusahaan asing, pada 2009 Lotte Group dari Korea menyerbu Indonesia dengan langkah strategis yaitu mengambil alih Makro yang awalnya dimiliki oleh SHV Holding NV asal Belanda. Untuk akuisisi tersebut Lotte mengeluarkan dana sekitar US\$223 juta. Lotte Group yang dirintis oleh Shin Kyuk Ho pada 1973, kini memilki 45 anak usaha yang bergerak dalam bidang perhotelan, makanan, distribusi, ritel, kimia, dan jasa konstruksi. Grup ini merambah bisnis ritel sejak 1979, mengoperasikan lebih dari 90 gerai di berbagai negara, antara lain Cina, Rusia, Vietnam, dan India. Lotte Group adalah grup bisnis kelima terbesar di Korea Selatan dengan total aset mencapai 31 miliar Euro dan pendapatan bersih sebesar 23 miliar Euro pada 20073. Peta persaingan ritel semakin ketat, setelah 40\% saham Carrefour yang merupakan leader hypermarket diakuisisi oleh CT Corporation anak perusahaan Grup Para dengan nilai sekitar US\$ 350 juta pada tahun 2010.

Sedangkan di Jawa Tengah, berdasarkan data statistik, jumlah pasar tradisional pada 2004 mencapai 1.496, sedangkan pasar modern berjumlah 232. Bila dibandingkan dengan data pada 2008, jumlah pasar tradisional hanya mencapai 1.443 sedangkan pasar modern mencapai 399. Berangkat dari data tersebut menunjukkan, pasar tradisional mengalami pertumbuhan negatif

\footnotetext{
${ }^{2}$ http://www.datacon.co.id/Ritel-2011Profillndustri.html

${ }^{3}$ Ibid.
} 
karena jika diprosentase pada 2004, pasar tradisional 86,5 persen, sedangkan pasar modern 13,5 persen. Pada tahun 2008, pasar tradisional mengalami penurunan menjadi sebesar 78,3 persen sedangkan pasar modern menjadi 21,7 persen. Pasar tradisional mengalami penyusutan sebesar 8,2 persen. Pada tahun 2010 pasar modern di Jawa Tengah diperkirakan mengalami pertumbuhan mencapai $10,2 \%(1.852 \text { gerai })^{4}$.

Berdasarkan data, secara keseluruhan pasar tradisional di Kota Semarang sebanyak 67 buah. Untuk pasar kota sebanyak 9 buah yang terdapat di Kecamatan Semarang Selatan, Semarang Tengah, Banyumanik, Ngaliyan dan Kecamatan Semarang Timur. Kecamatan Semarang Selatan dan Semarang Tengah memiliki jumlah pasar kota terbesar yaitu masing masing 3 buah. Sedangkan pasar wilayah terdapat di Kecamatan Gunungpati 1 buah, Pedurungan 2 buah, Semarang Selatan 3 buah, Semarang Tengah 5 buah, Candisari 2 buah, Gayamsari dan Mijen masing masing 1 buah, Ngaliyan 2 buah, dan Kecamatan Semarang Barat 4 buah, sehingga jumlah total pasar wilayah yang ada di Kota Semarang sebanyak 21 buah. Selain itu juga terdapat pasar skala lingkungan dengan lokasi yang rata rata menyebar di wilayah Kota Semarang dengan jumlah total 37 buah yang tersebar di Kecamatan Genuk, Pedurungan, Banyumanik, Gayamsari, Mijen, Ngaliyan, Semarang Barat, Semarang Timur, Semarang Utara, Tembalang, Tugu, dan kecamatan Gajahmungkur ${ }^{5}$.

Sedangkan di Kota Semarang terdapat 11 hypermarket dengan persebaran di Kec. Pedurungan 1 buah, Kec. Semarang Selatan 3 buah, Kec. Banyumanik 3 buah dan paling banyak terdapat di Kec. Semarang Tengah terdapat 4 buah. Sedang supermarket ada 23 buah yang tersebar di wilayah Kec. Pedurungan, Semarang Selatan, Semarang Tengah, Banyumanik, Candisari, Gayamsari, Ngaliyan, Semarang Barat, Semarang Timur, Tugu dan Kec. Gajahmungkur, sedangkan supermarket paling banyak terdapat di Kec. Semarang Barat. Sementara, minimarket yang ada di Kota Semarang didominasi oleh Indomaret dan Alfamart. Minimarket ini tersebar di seluruh wilayah kecamatan yang ada di Kota Semarang dengan jumlah 244 buah

\footnotetext{
${ }^{4}$ Ibid.

${ }^{5}$ MasterPlan Pengembangan Pola Perpasaran Kota Semarang
} 
minimarket. Sama halnya dengan Minimarket, pertokoan yang ada di Kota Semarang juga menyebar di seluruh wilayah kecamatan yang ada di wilayah Kota Semarang dengan kisaran $3-80$ buah pertokoan per kecamatan. Jumlah pertokoan yang ada di seluruh wilayah Kota Semarang sebanyak 445 buah. Berdasarkan rincian tersebut, total jumlah pasar modern secara keseluruhan mencapai 723 pasar modern ${ }^{6}$.

Pertumbuhan pasar ritel modern yang demikian pesat, satu sisi menunjukkan tingkat investasi yang tinggi di Indonesia yang dengan demikian diharapkan akan mewujudkan tingkat pertumbuhan ekonomi yang stabil, namun di sisi lain keberadaan pasar-pasar ritel modern juga merupakan ancaman terhadap pasar-pasar tradisional yang pelan tapi pasti setiap tahun mengalami penurunan jumlah. Berdasarkan hal tersebut makalah ini berusaha menganalisis fenomena tentang semakin besarnya tekanan pasar ritel modern terhadap keberadaan pasar tradisional dengan rumusan masalah bagaimanakah perlindungan terhadap pasar tradisional di tengah ekspansi pasar ritel modern?

\section{Pembahasan}

Eksistensi pasar menjadi sangat penting untuk diperbincangkan, mengingat pasar merupakan tempat bertemunya pembeli dan penjual, proses bertemunya pembeli dan penjual ini menjadi indikator tingkat perekonomian masyarakat. Semakin besar volume transaksi yang terjadi di pasar menunjukkan perekonomian yang stabil dan lebih jauh lagi kegiatan ekonomi yang terjadi di pasar merupakan cerminan tingkat kesejahteraan masyarakat. Berdasarkan Pasal 1 ayat 1 Peraturan Presiden No. 112 tahun 2007 tentang Penataan dan Pembinaan Pasar Tradisional, Pusat Perbelanjaan dan Toko Modern, Pasar merupakan area tempat jual beli barang dengan jumlah penjual lebih dari satu baik yang disebut sebagai pusat perbelanjaan, pasar tradisional, pertokoan, mall, plasa, pusat perdagangan maupun sebutan lainnya.

Dalam Perpres No. 112 tahun 2007 tersebut pasar dengan segala bentuknya baik pasar tradisional maupun pasar modern di mall, plasa maupun pusat-pusat perdagangan merupakan tempat jual beli barang. Tempat jual beli 
barang yang terjadi melibatkan pengusaha kecil dan modal kecil dikategorikan sebagai pasar tradisional. Secara normatif pengertian pasar tradisional disebutkan dalam Pasal 1 ayat 2 Perpres No. 112 tahun 2007 bahwa pasar tradisional adalah pasar yang dibangun dan dikelola oleh pemerintah, pemerintah daerah, swasta, badan usaha milik Negara dan badan usaha milik daerah termasuk kerjasama dengan swasta dengan tempat usaha berupa toko, kios, los dan tenda yang dimiliki/dikelola oleh pedagang kecil, menengah, swadaya masyarakat atau koperasi dengan usaha skala kecil, modal kecil dan dengan proses jual beli barang dagangan melalui tawar menawar. Sedangkan toko modern adalah toko dengan sistem pelayanan mandiri,menjual berbagai jenis barang secara eceran yang berbentuk Minimarket, Supermarket, Department Store, Hypermarket ataupun grosir yang berbentuk Perkulakan."

Kriteria pasar tradisional disebutkan dalam Pasal 4 Peraturan Menteri Dalam Negeri No. 20 tahun 2012 tentang Pengelolaan dan Pemberdayaan Pasar Tradisional, antara lain:

a. dimiliki, dibangun dan/atau dikelola oleh pemerintah daerah;

b. transaksi dilakukan secara tawar menawar;

c. tempat usaha beragam dan menyatu dalam lokasi yang sama; dan

d. sebagian besar barang dan jasa yang ditawarkan berbahan baku lokal.

Kriteria pasar tradisional khususnya pada poin keempat menunjukkan bahwa pasar tradisional merupakan pasar yang pelakunya menggunakan bahan baku lokal yang nota bene-nya pelakunya adalah mereka yang tergolong dalam usaha kecil menengah. Keberadaan pasar tradisional sebagai tempat bertemunya para penjual dari kalangan masyarakat lapisan bawah juga ditunjukkan oleh ciri khas pasar yang dalam transaksinya dilakukan secara tawar menawar.

Perlindungan terhadap eksistensi pasar tradisional mutlak untuk dilakukan dengan melakukan upaya untuk mensinergikan kekuatan pasar modern dengan kelemahan pasar tradisional. Keberadaan pasar modern harus dapat menjaga eksistensi pasar tradisional dan bukan sebaliknya. Salah satu cara yang dapat dilakukan oleh pemerintah adalah dengan menerbitkan beberapa peraturan perundang-undangan yang secara substansiil mengatur 
pola hubungan antara pasar tradisional dengan pasar modern. Pengaturan pola hubungan pasar modern dengan pasar tradisional tersebut diharapkan ekspansi dan perkembangan pasar modern bukan lagi merupakan ancaman terhadap eksistensi pasar tradisional. Sehingga hukum yang berbentuk peraturan perundangan tersebut mampu mewujudkan perlindungan terhadap pasar tradisional ${ }^{7}$.

Konsep perlindungan terhadap pasar tradisional sesungguhnya sudah diupayakan oleh pemerintah dalam Perpres No. 112 tahun 2007. Dalam Pasal 4 disebutkan tentang persyaratan pendirian pusat perbelanjaan dan toko modern. Untuk mendirikan pusat perbelanjaan dan toko modern harus memenuhi beberapa persyaratan, antara lain;

1. harus memperhitungkan kondisi sosial ekonomi masyarakat dan keberadaan pasar tradisional, usaha kecil dan usaha menengah yang ada di wilayah dimana pasar modern tersebut hendak dibangun;

2. pendirian pasar modern juga harus memperhatikan jarak dengan pasar tradisional yang telah ada sebelumnya;

3. pasar modern harus menyediakan areal parkir paling sedikit seluas kebutuhan parkir 1 (satu) unit kendaraan roda empat untuk setiap $60 \mathrm{~m} 2$ (enam puluh meter per segi) luas lantai penjualan toko modern, yang pengoperasionalisasinya bisa kerjasama dengan pihak lain; dan

4. pasar modern harus menyediakan fasilitas yang menjamin tempat bersih, sehat (hygienis), aman, tertib dan ruang publik yang nyaman.

Berkaitan dengan ketentuan-ketentuan tersebut, Menteri Perdagangan menerbitkan Peraturan Menteri Perdagangan No. 53/M-DAG/PER/12/2008 tentang Pedoman Penataan dan Pembinaan Pasar Tradisional, Pusat Perbelanjaan dan Toko Modern. Dalam Peraturan Menteri Perdagangan

${ }^{7}$ Menurut Hernado de Soto, hukum yang baik adalah hukum yang menjamin bahwa kegiatan ekonomi dan sosial yang diaturnya dapat berjalan dengan efisien, begitu pula sebaliknya hukum yang buruk adalah hukum yang mengacaukan atau justru menghalangi kegiatan usaha sehingga menjadi tidak efisien. Lihat Hernado de Soto, Masib Ada Jalan Lain, Revolusi Tersembunyi di Negara Ketiga, terjemahan oleh Masri Maris, Jakarta, Yayasan Obor Indonesia, 1991. 
tersebut dijelaskan bahwa hal-hal yang dianalisa berkaitan dengan pendirian pasar ritel modern adalah kondisi sosial ekonomi masyarakat dan keberadaan pasar tradisional sebagaimana disebutkan dalam Perpres No. 112 tahun 2007 diatas. Analisa kondisi sosial ekonomi masyarakat dan keberadaan pasar tradisional serta usaha mikro, kecil dan menengah (UMKM) antara lain berkaitan dengan struktur penduduk menurut mata pencaharian dan pendidikan, tingkat pendapatan ekonomi rumah tangga, kepadatan dan pertumbuhan penduduk, kemitraan dengan UMKM lokal, penyerapan tenaga kerja lokal, ketahanan dan pertumbuhan pasar tradisional sebagai sarana bagi UMKM lokal, keberadaan fasilitas sosial dan fasilitas umum yang sudah ada, dampak positif dan negatif yang diakibatkan oleh jarak antara bypermarket dengan pasar tradisional yang telah ada sebelumnya dan tanggung jawab sosial perusahaan (Corporate Social Responsibility).

Analisa yang berkaitan dengan kondisi sosial masyarakat tersebut harus dilakukan oleh lembaga independen. Disamping itu, hasil analisis tersebut juga merupakan satu kesatuan yang harus diikutsertakan pada saat pengajuan ijin untuk mendirikan pasar modern. Hal lain yang harus diperhatikan sebelum pendirian pasar dan atau toko modern adalah, lokasi pendirian harus mengacu pada rencana atau ruang wilayah kabupaten/kota dan juga rencana detail tata ruang kabupaten/kota serta memperhatikan pengaturan tentang zonasinya. Untuk menentukan jenis pasar modern dalam Perpres No. 112 tahun 2007 juga disebutkan tentang batasan luas bangunannya;

1. Departemen store harus mempunyai luas bangunan diatas $400 \mathrm{~m} 2$;

2. Perkulakan harus mempunyai luas bangunan 5. $000 \mathrm{~m} 2$;

3. Hypermarket harus mempunyai luas bangunan diatas $5.000 \mathrm{~m} 2$;

4. Supermarket harus mempunyai luas bangunan antara $400 \mathrm{~m} 2-5$. $000 \mathrm{~m} 2$;

5. Minimarket merupakan toko modern yang luas bangunannya kurang dari $400 \mathrm{~m} 2$.

Saat ini banyak jenis format dalam pasar modern modern. Secara umum berbagai banner (brand) pelaku usaha dapat dikelompokkan sebagai berikut: 
Perlindungan Terbadap Pasar Tradisional

Tabel 1

Ritel Modern Dalam Berbagai Format, Format Contoh Banner (Brand)

\begin{tabular}{|l|l|}
\hline \multicolumn{1}{|c|}{ Format } & \multicolumn{1}{c|}{ Contoh Brand } \\
\hline Hypermarket & $\begin{array}{l}\text { Carrefour, Giant, Hypermart, Yogya, Lion } \\
\text { Superindo }\end{array}$ \\
\hline Supermarket & $\begin{array}{l}\text { Griya, Alfa, Sri Ratu, Hero, Ramayana, } \\
\text { Ada }\end{array}$ \\
\hline Minimarket & Alfamart, Indomart, Yomart, Alfa-Midi \\
\hline Perkulakan & Makro (Lotte Mart), Indogrosir \\
\hline Convenience Store & Circle K, Starmart \\
\hline Warehouse & Ace Hardware, Index \\
\hline Department Store & Metro, Matahari, Sogo \\
\hline Drugstore \& Personal & Watson, Guardian, Boston, Century, K-24 \\
\hline Electronic Specialist & E-City, E-Solution \\
\hline Bookstore & Gramedia, Gunung Agung, Toga Mas \\
\hline
\end{tabular}

Sumber: Diolah dari berbagai sumber

Sebelum menjalankan usahanya, pasar modern yang akan didirikan harus memenuhi perijinan yang sudah ditetapkan. Untuk pertokoan, mall, plaza, dan pusat perdagangan wajib memiliki Izin Usaha Pusat Perbelanjaan (IUPP) sedangkan minimarket, supermarket, department store, hypermarket, dan perkulakan wajib memiliki Izin Usaha Toko Modern (IUTM). Jenis-jenis izin diatas yaitu IUPP dan IUTM diterbitkan oleh Bupati/Walikota dan Gubernur untuk Pemerintah Provinsi DKI Jakarta. Disamping itu, setiap pedagang atau pelaku usaha pasar yang akan mengajukan izin usaha harus menyertai studi kelayakan (termasuk AMDAL) dan rencana kemitraan dengan usaha kecil.

Namun ketentuan-ketentuan peraturan diatas belum mampu mensinergikan antara pasar modern dengan pasar tradisional, sehingga perlu diupayakan cara lain agar sinergi keduanya dapat berjalan dengan baik. Hal ini, 
antara lain dapat dilakukan dengan cara meningkatkan peran pemerintah daerah. Dalam era otonomi sekarang, pemerintah daerah mempunyai peran yang besar karena dia bertanggungjawab untuk mewujudkan keberlangsungan pasar tradisional di daerahnya dengan lebih memperhatikan lokasi dari ritel modern yang ingin melakukan kegiatan usahanya. Keberadaan pasar-pasar modern atau minimarket yang sangat berdekatan menunjukkan lemahnya pengawasan yang dilakukan oleh pemerintah daerah terhadap perkembangan pasar modern, oleh karena itu dalam hal jam operasional pasar modern baik hypermarket, departemen store maupun supermarket, sebagaiman disebutkan dalam Perpres No. 112 tahun 2007 bahwa;

a. Untuk hari Senin sampai dengan Jumat, pukul 10.00 sampai dengan pukul 22.00 waktu setempat.

b. Untuk hari Sabtu dan Minggu, pukul 10.00 sampai dengan pukul 23.00 waktu setempat.

c. Untuk hari besar keagamaan, libur nasional atau hari tertentu lainnya, Bupati/Walikota atau Gubernur untuk Pemerintah Provinsi Daerah Khusus Ibukota Jakarta dapat menetapkan jam kerja melampaui pukul 22.00 waktu setempat.

Pembatasan jam operasi pasar modern tersebut harus diperketat dan dilakukan pengawasan yang sungguh-sungguh. Berkaitan dengan kerjasama antara pasar modern dengan usaha kecil menengah, meskipun sudah ada upaya untuk mensinergikan antara pasar tradisional dengan pasar modern sebagaimana tercermin dalam Perpres 112 tahun 2007 yang mengamantkan keharusan bagi pasar modern untuk menyediakan tempat usaha dengan harga jual atau biaya sewa sesuai dengan kemampuan usaha kecil atau yang dapat dimanfaatkan oleh usaha kecil melalui kerjasama lain dalam rangka kemitraan (Pasal 6) belum berjalan dengan baik. Kerjasama yang selama ini antara lain diwujudkan dalam bentuk pemasokan yang dibingkai dalam bentuk perjanjian tertulis dengan ketentuan bahwa pasar modern tidak memungut biaya administrasi pendaftaran barang dari pemasok usaha kecil dan pembayaran kepada pemasok usaha kecil dilakukan secara tunai, atau dengan alasan teknis tertentu dapat dilakukan dalam jangka waktu 15 (lima belas) hari setelah seluruh dokumen penagihan diterima. Namun, kasus trading term yang dilakukan oleh Carefour dan berakibat pada penjatuhan hukuman denda oleh 
Komisi Pengawas Persaingan Usaha (KPPU) terhadap Carefour merupakan contoh hubungan yang tidak baik antara usaha kecil mikro dengan perusahaan ritel besar atau pasar modern.

Memperhatikan regulasi atau kebijakan di bidang perpasaran sebagaimana dikemukakan diatas, pada dasarnya mempunyai filosofi agar keberadaan pasar-pasar modern tidak menjadi ancaman bagi keberadaan pasarpasar tradisional. Dalam kaitan ini pemerintah berkewajiban untuk menciptakan level of playing field yang adil bagi para pelaku usaha, melindungi pihak yang lemah dari eksploitasi ekonomi pihak yang kuat, membuat peraturan yang tegas, jelas dan transparan, memberikan sanksi yang tegas bagi para pelaku usaha yang melanggarnya baik sanksi pidana maupun sanksi administratif, bertindak sebagai wasit, jujur dan bertanggungjawab8 ${ }^{8}$.

Disamping itu, untuk memberikan perlindungan terhadap keberadaan pasar tradisional adalah dengan melakukan zonasi pasar sebagaimana ditentukan dalam Perpres No. 112 tahun 2007. Zonasi pasar modern ditentukan dalam Pasal 5 yang mengatur bahwa perkulakan hanya boleh berlokasi pada atau pada akses sistem jaringan jalan arteri (jalan umum yang berfungsi melayani angkutan utama dengan ciri perjalanan jarak jauh, kecepatan rata-rata tinggi, dan jumlah jalan masuk dibatasi secara berdaya guna) atau jalan kolektor (jalan umum yang berfungsi melayani angkutan pengumpul atau pembagi dengan ciri perjalanan jarak sedang, kecepatan ratarata sedang, dan jumlah jalan masuk dibatasi) primer atau arteri sekunder.

Pasar modern yang berbentuk hypermarket dan pusat perbelanjaan hanya boleh berlokasi pada atau pada akses sistem jaringan jalan arteri atau kolektor dan tidak boleh berada pada kawasan pelayanan lokal atau lingkungan di dalam kota/perkotaan. Sedangkan supermarket dan department store tidak boleh berlokasi pada sistem jaringan jalan lingkungan (jalan umum yang berfungsi melayani angkutan lingkungan dengan ciri perjalanan jarak dekat, dan kecepatan rata-rata rendah low on average) dan tidak boleh berada pada kawasan pelayanan lingkungan di dalam kota/perkotaan.

8 Lucianus Budi Kagramanto, 2009, Harmonisasi Kebijakan dan Hukum Persaingan Usaha Dalam meningkatkan Kesejabteraan Masyarakat, Pidato Pengukuhan Dalam Bidang Ilmu Hukum Persaingan Usaha, Fakultas Hukum Universitas Airlangga Surabaya, 6 Juni 2009 
Sementara itu, untuk minimarket boleh berlokasi pada setiap sistem jaringan jalan, termasuk sistem jaringan jalan lingkungan pada kawasan pelayanan lingkungan (perumahan) di dalam kota/perkotaan. Sistem jaringan jalan ada dua macam yaitu sistem jaringan jalan primer dan sistem jaringan jalan sekunder. Sistem jaringan jalan primer merupakan sistem jaringan jalan dengan peranan pelayanan distribusi barang dan jasa untuk pengembangan semua wilayah di tingkat nasional, dengan menghubungkan semua simpul jasa distribusi yang berwujud pusat-pusat kegiatan. Sedangkan sistem jaringan jalan sekunder adalah sistem jaringan jalan dengan peranan pelayanan distribusi barang dan jasa untuk masyarakat di dalam kawasan perkotaan.

Dalam tataran implementatif zonasi pasar dilakukan oleh pemerintah daerah, oleh karena itu jika pemerintah daerah tidak melakukan fungsi dan tugasnya tersebut, pemerintah daerah dapat digugat dengan menggunakan mekanisme actio popularis atau citizen law suite ${ }^{9}$. Pihak penggugat dalam hal ini adalah setiap orang yang berdomisili di daerah dimana ketentuan atau peraturan yang mengatur tentang zonasi pasar tidak diterbitkan sehingga berakibat pada terdesaknya pasar tradisional oleh pasar modern.

Disamping melalui zonasi pasar, perlindungan terhadap pasar tradisional dapat juga dilakukan dengan melakukan penegakan hukum terhadap ketentuan yang tertuang dalam Perpres No. 112 tahun 2007 dan juga Permendag No. 53/M-DAG/PER/12/2008. Namun, yang menjadi hambatan dalam penegakan hukum ini adalah sanksi yang diterapkan dalam peraturan tersebut kurang tegas sehingga belum menjerakan bagi para pelaku usaha. Oleh karenanya diperlukan keberanian bagi pemerintah untuk segera menerbitkan peraturan perundangan yang memberikan arahan yang memuat tentang master plan terhadap perlindungan pasar tradisional atau setidak-tidaknya mensinergikan antara kepentingan pasar tradisional dan pasar modern.

${ }^{9}$ Rahadi Wasi Bintoro, 2010, Aspek Hukum Zonasi Pasar Tradisional dan Pasar Modern, Jurnal Dinamika Hukum, Vol. 10 No. 3 September, hal. 362 
Perlindungan Terhadap Pasar Tradisional

\section{Kesimpulan}

Berdasarkan uraian dapat disimpulkan bahwa perlindungan terhadap pasar tradisional harus dilakukan ditengah ekspansi pasar modern yang kian pesat perkembangannya. Perlindungan tersebut dapat dilakukan antara lain dengan cara memberlakuan zonasi keberadaan pasar modern sebagaimana ditentukan dalam Perpres No. 112 tahun 2007 dan No. 53/MDAG/PER/12/2008. Perlindungan terhadap pasar tradisional juga dapat dilakukan dengan cara memperketat proses perijinan dan penegakan hukum. Semakin berkembangnya pasar modern dengan berbagai bentuknya, antara lain disebabkan oleh lemahnya penegakan hukum. Aparat penegak hukum khususnya aparat penegak hukum daerah tidak melakukan fungsi dan tugasnya dengan baik, pasar modern berkembang dengan pesat dan melakukan penetrasi terhadap pasar-pasar tradisional sehingga dalam perkembangannya lebih mudah menemukan pasar modern daripada pasar tradisional. Metoda penegakan hukum yang dapat dipakai antara lain dengan mengajukan perusahaan 'nakal' ke meja hijau. Oleh karena itu, sangat penting untuk dibuat sebuah peraturan perundangan yang memiliki daya ikat bagi setiap pelaku ekonomi maupun pembuat kebijakan dalam industri ritel yang memuat sanksi bagi para pelanggarnya dan karenanya tidak cukup hanya dituangkan dalam bentuk Peraturan Presiden maupun Peraturan Menteri tetapi harus dituangkan dalam bentuk undang-undang. 


\section{DAFTAR BACAAN}

Dinas Perdagangan Kota Semarang, 2011, MasterPlan Pengembangan Pola Perpasaran Kota Semarang

Bintoro, Rahadi Wasi, 2010, Aspek Hukum Zonasi Pasar Tradisional dan

Pasar Modern, Jurnal Dinamika Hukum, Vol. 10 No. 3 September

Budi Kagramanto, Lucianus, 2009, Harmonisasi Kebijakan dan Hukum Persaingan Usaha Dalam meningkatkan Kesejahteraan Masyarakat, Pidato Pengukuhan Dalam Bidang Ilmu Hukum Persaingan Usaha, Fakultas Hukum Universitas Airlangga Surabaya, 6 Juni 2009

Wyati Saddewisasi, dkk, 2011, Analisis Dampak Usaba Ritel Modern Terhadap Usaha Ritel Tradisional (Studi Kasus Di Wilayah Kecamatan Gungungpati, Tembalang dan Banyumanik), Jurnal Riptek, Vol.5 No.I Tahun 2011

Sulistyo, Heru, Budhi Cahyono, 2010, Model Pengembangan Pasar Tradisional Menuju Pasar Sehat di Kota Semarang, Jurnal Ekobis, Volume 11 No. 2 Juli 2010

Suryadarma, Daniel, dkk, 2007, Laporan Penelitian Dampak Supermarket terhadap Pasar dan Pedagang Ritel Tradisional di Daerah Perkotaan di Indonesia, Jakarta: Lembaga Penelitian Smeru

\section{Peraturan Perundang-Undangan;}

Undang-Undang No. 20 tahun 2008 tentang Usaha Mikro Kecil dan Menengah

Undang-Undang No. 5 tahun 1999 tentang Larangan Praktek Monopoli dan Persaingan Usaha Tidak Sehat

Peraturan Presiden No. 112 tahun 2007 tentang Penataan dan Pembinaan Pasar Tradisional, Pusat Perbelanjaan dan Toko Modern

Peraturan Pemerintah Nomor 32 Tahun 1998 tentang Pembinaan dan Pengembangan Usaha Kecil 
Perlindungan Terbadap Pasar Tradisional

Peraturan Pemerintah Nomor 44 Tahun 1997 tentang Kemitraan

Peraturan Menteri Perdagangan No. 53/M-DAG/PER/12/2008 tentang Pedoman Penataan dan Pembinaan Pasar Tradisional, Pusat Perbelanjaan dan Toko Modern

Peraturan Menteri Dalam Negeri No. 20 tahun 2012 tentang Pengelolaan dan Pemberdayaan Pasar Tradisional

Website;

http://www.datacon.co.id/Ritel-2011Profillndustri.html 